\title{
Response of Fish Pond Effluent on Soil Chemical Properties and Growth of Cucumber (Cucumis sativus) in Igbariam South Eastern, Nigeria
}

\author{
Nsoanya Leonard Ndubuisi* \\ Department of Soil Science, Chukwuemeka Odumegwu Ojukwu University, Igbariam Campus, \\ Anambra State, Nigeria \\ *Corresponding author
}

\begin{tabular}{|l|}
\hline K e y w o r d s \\
Fish Pond Effluent; \\
Soil Chemical \\
Properties, Growth \\
Parameters, Soil \\
Fertility, Cucumber, \\
NPK fertilizer \\
\hline Article Info \\
\hline $\begin{array}{l}\text { Accepted: } \\
\text { 20 January } 2019 \\
\text { Available Online: } \\
\text { 10 February } 2019\end{array}$ \\
\hline
\end{tabular}

A B S T R A C T
The response of fish pond effluent on soil chemical properties and growth of cucumber (Cucumis sativus) in Igbariam South Eastern, Nigeria was studied during 2018 farming season at the Teaching and Research Farm of the Department of Soil Science, Faculty of Agriculture, Chukwuemeka Odumegwu Ojukwu University, Igbariam Campus, Anambra State, Nigeria. The field experiment which was laid out in a Randomized Complete Block Design (RCBD), comprised three treatments and three replications as follows: T1 Control (No treatment): T2 - Fish Pond Effluent (40,000 litres/hectare) and T3 - Fish Pond Effluent (20,000 litres/hectare) $+200 \mathrm{~kg} /$ ha fertilizer (NPK 20: 10:10). Results obtained revealed that, the treatments were significantly $(\mathrm{P}=0.05)$ different on some chemical properties of soil and Growth Parameters of Cucumber. The highest values of the Soil Chemical Properties (Available Phosphorus -6.6 mg/kg; Total Nitrogen -0.8g/kg; Organic Carbon $-5.8 \mathrm{~g} / \mathrm{kg}$; Organic Matter $-10.1 \mathrm{~g} / \mathrm{kg}$ were recorded at the plot where Fish Pond Effluent was applied at the rate of 20,000 litres/ hectare with $200 \mathrm{~kg} / \mathrm{ha}$ of fertilizer (NPK 20: 10:10). Fish Pond Effluent had no significant effect on the $\mathrm{pH}$ of the soil as the $\mathrm{pH}$ of the treated plots was almost at par with the Control. While the highest values of Number of leaves (37.9), Vine length $(39.47 \mathrm{~cm})$ and Number of Branches $(2.80)$ were also recorded at the plot where fish pond effluent was applied at the rate of $20,000 \mathrm{~L} / \mathrm{ha}$ with $200 \mathrm{~kg} / \mathrm{ha}$ of NPK fertilizer (20:10:10) at 7 WAP.

\section{Introduction}

Cucumber (Cucumis sativus) is an edible fruit of the Cucumber plant which is eaten fresh in salad and other foods and some of them have high content of vitamins A and C (Peet, 2001). Regular consumption of Cucumber fruit has various medicinal effects such as promotion of healthy growth of hair, softening of skin texture, curing of skin infection like Eczema and facilitation of weight loss. Dr A. Shrivastava et al., (2013); Kashif et al., (2008) reported that, Cucumber can also be helpful for both high and low blood pressure due to high content of potassium (50-80mg/100g). Paul et al., (2012) also reported that aqueous extract of Cucumber can have good effectiveness on wound healing. 
According to Tindall (1986) and Alter (2000), Cucumber is a tender warm season vegetable crop that produces well when given proper care and protection. Cucumber plant grows well on fertile soil and requires nutrient from seedling stage to maturity. In view of this, Cucumber requires fertilizer application either in the form of inorganic or organic for increasing the yield per unit area and improving the fertility of the soil.

Many researchers have opined that, the use of inorganic fertilizers increased the growth and yield of Cucumber (Agba and Enya, 2005; Lawal, 2000; Grubben, 1997). According to Eifediyi and Remison (2009), the Cucumber vegetative characters such as vine length, number of leaves, number of branches and leaf area responded significantly to applied inorganic fertilizers up to $400 \mathrm{~kg} / \mathrm{ha}$ which resulted to the development of the crop and its photosynthetic apparatus.

However, due to the excessive degradations of soils in the South Eastern Nigeria by high rainfall regime; high cost and scarcity of inorganic fertilizers as well as the global desire for organically produced foodstuff (Adeniyan et al., 2011), there tends to be a shift by researchers to development of fertilizer management technologies that utilized organic fertilizers or combination of both organic and inorganic fertilizers (Granstedt, 1992; Iren et al., 2015; Nweke and Nsoanya, 2013; Nsoanya and Nweke, 2015).

Food and Agriculture Organization of the United Nation (FAO) (2014) reported that, combination of fish farming and crop cultivation was well developed in China and the nutrient rich residues that settled in fish ponds can be utilized for soil fertility improvement. Results obtained by Udoh et al., (2016) revealed that, pond waste water positively supported the growth of garden eggs at equal level as did Pig manure and gave higher yields than Poultry Litter and NPK 15: 15: 15 when applied at rates that supplied $\mathrm{N}$ at the rate of $150-300 \mathrm{~kg} \mathrm{ha}^{-1}$.

Ojobor and Tobih (2015) also reported that, fish Pond effluent increased the dry matter yield and soil chemical properties such as Available phosphorus, water soluble Potassium, Calcium and Magnesium and this increase was attributed to the high nutrient content of Fish Pond Effluent.

However, the effect of fish pond effluent on growth of Cucumber and Soil Chemical Properties of Igbariam has not been widely studied, hence this research.

The objective of this study was to investigate the Response of Fish Pond Effluent as Organic Fertilizer on Growth of Cucumber (Cucumis sativus) and some Soil Chemical Properties in Igbariam, South Eastern Nigeria.

\section{Materials and Methods}

\section{Location and characteristics of the experimental site}

The experiment was conducted during 2018 farming season at the Teaching and Research Farm of the Department of Soil Science, Faculty of Agriculture, Chukwuemeka Odumegwu Ojukwu University, Igbariam Campu, Anambra State Nigeria. Igbariam falls within the derived savanna zone of Nigeria and is located at Latitude $06^{\circ} 14^{1} \mathrm{~N}$ and longitude $06^{\circ} 45^{1} \mathrm{E}$ (Anambra State Ministry of Science and Technology Meteorological Station, Igbariam). The pattern of rainfall is bimodal between April and October. The total annual rainfall is between $1500 \mathrm{~mm}$ and $2000 \mathrm{~mm}$; while the average temperature ranges between $21^{\circ} \mathrm{C}$ and $30^{\circ} \mathrm{C}$. The Relative Humidity $(\mathrm{RH})$ of the area is moderately high and the highest $\mathrm{RH}$ of $80 \%$ 
and lowest $\mathrm{RH}$ of $58 \%$ were recorded during the wet and dry seasons respectively. The soil of the study area is loamy sand.

\section{Land preparation, experimental design and treatment allocation}

The experimental field was cleared and tilled with the help of hoe. Thereafter, it was marked out into plots. The area of the experimental site was $10 \mathrm{~m} \times 14 \mathrm{~m}=140 \mathrm{~m}^{2}$.

The experiment was laid out in a Randomized Complete Block Design (RCBD) which comprised three treatments and three replications, giving a total of 9 plots. The size of each plot was $2 \mathrm{~m} \times 2 \mathrm{~m}=4 \mathrm{~m}^{2}$ with a distance of $1 \mathrm{~m}$ between the plots and $2 \mathrm{~m}$ between the blocks. Treatment material -fish pond effluent was applied to plots in accordance with the allocated rates one week before planting to allow for decomposition end mineralization of nutrients. The treatments were made up of three levels: $\mathrm{T}_{1}$ Control (No treatment), $\mathrm{T}_{2}-$ Fish Pond Effluent - 40, 000 litres/ha; $\mathrm{T}_{3}-$ Fish Pond effluent 20,000 litres/ha $+200 \mathrm{~kg} /$ ha NPK fertilizer (20: 10:10).

Planting of two Cucumber seeds (Poinsett) per hole was carried out one week after the application of fish pond effluent at the spacing of $50 \mathrm{~cm} \times 60 \mathrm{~cm}$. The seedlings were later thinned to one plant per hole, while empty stands were supplied. Weed control was done manually using hoe at two weeks interval till harvest to reduce competition between the Cucumber plants and weeds for the available nutrients, water and light.

\section{Data collection}

Composite soil samples were initially collected randomly from different locations of the experimental site using a soil auger at a depth of $0-20 \mathrm{~cm}$ for pre-planting analyses of physico-chemical properties of the soil of the study area (Table 1).

Soil samples were also collected at the end of the experiment from each plot for determining some soil chemical properties (namely; $\mathrm{pH}$, Organic Matter, Total Nitrogen and Available Phosphorus) of Igbariam. Soil $\mathrm{pH}$ was determined with Digital $\mathrm{pH}$ meter; Organic Matter was determined according to Walkley and Black (1934) Wet Oxidation method. Total Nitrogen was determined by Kjeldahl digestion method of Black et al., (1965); while Available Phosphorus was determined by the method of Bray and Kurtz (1945).

Data collection on Growth Parameters of Cucumber plants was carried out at the $5^{\text {th }}, 6^{\text {th }}$ and 7 th weeks after planting (WAP). Five Cucumber plants were randomly selected from each plot and tagged for the measurement of the following growth parameters: (Number of leaves, Vine length, Leaf Area and Number of Branches in order to access the effect of Fish Pond Effluent when applied singly as well as its combination with NPK fertilizer 20;10;10.

The Data generated were subjected to Analysis of variance (ANOVA) test according to Steel and Torrie (1980). While Treatment means were compared using the Least Significant Difference (LSD) at $0.05 \%$ level of probability.

\section{Results and Discussion}

\section{Effect on soil chemical properties}

The results of the study on some soil chemical properties presented on Table 2 showed that, fish Pond Effluent when applied singly as well as its combination with NPK fertilizer (20:10:10) increased some soil chemical properties (namely; Available Phosphorus, Total Nitrogen, Organic Carbon and Organic 
Matter) when compared with the Control. Fish Pond Effluent had no significant influence on the $\mathrm{pH}$ as the $\mathrm{pH}$ of the treated plots was almost at per with the Control. The results on Total Nitrogen, Available phosphorus, organic carbon and organic Matter indicated significant $(\mathrm{P}=0.05)$ difference among the treatments. The highest values of the Soil Chemical Properties $(\mathrm{P}$ $6.6 \mathrm{mg} / \mathrm{kg} ; \mathrm{N}-0.8 \mathrm{~g} / \mathrm{kg}, \mathrm{OC}-5.8 \mathrm{~g} / \mathrm{kg}$ and $\mathrm{OM}$ $-10.1 \mathrm{~g} / \mathrm{kg}$ ) were recorded at the plot where Fish Pond Effluent was applied at 20,000L/ha with $200 \mathrm{~kg} / \mathrm{ha}$ of fertilizer (NPK 20:10:10). The plot where Fish Pond Effluent was applied alone at $40,000 \mathrm{~L} / \mathrm{ha}$ recorded the following values of Soil Chemical Properties (Available Phosphorus(P)-5.73mg/kg; Total Nitrogen $(\mathrm{N})-0.7 \mathrm{~g} / \mathrm{kg}$; Organic Carbon $(\mathrm{OC})-$ $4.4 \mathrm{~g} / \mathrm{kg}$ and Organic Matter(OM) $-7.6 \mathrm{~g} / \mathrm{kg})$ while the Control recorded the least values $(\mathrm{P}$ $4.7 \mathrm{mg} / \mathrm{kg}, \mathrm{N}-0.56 \mathrm{~g} / \mathrm{kg} ; \mathrm{OC}-3.4 \mathrm{~g} / \mathrm{kg}$ and $\mathrm{OM}-5.9 \% \mathrm{~g} / \mathrm{kg}$.

\section{Effect on growth parameters}

The results of the study on Growth Parameters of Cucumber presented on Tables $3,4,5$ and 6 showed that, fish pond effluent had great effect on the Number of leaves, Vine length, Number of branches and leaf area of cucumber plant at different stages of development when compared with the Control. Results presented on Table 3 revealed that, the treatments had significant effect on Number of leaves. The number of leaves increased from the $5^{\text {th }}$ to $7^{\text {th }}$ weeks after planting (WAP) in all the treatments when compared with the control. The highest number of leaves (37.93) was recorded at $7^{\text {th }}$ WAP in the plot where fish pond effluent was applied at 20,000 L/ha with $200 \mathrm{~kg} / \mathrm{ha}$ of NPK fertilizer (20:10:10), while the plot where fish pond Effluent was applied alone recorded 33.73 which was better than the value (20.93) recorded in control. Results on Table 4 revealed that, fish pond Effluent significantly influenced the Vine length of Cucumber at the $5^{\text {th }}, 6^{\text {th }}$ and $7^{\text {th }}$ WAP. The highest vine length $(39.47 \mathrm{~cm})$ was recorded at the plot that received fish pond effluent at $20,000 \mathrm{~L} / \mathrm{ha}$ combined with $200 \mathrm{~kg} / \mathrm{ha}$ fertilizer (NPK 20:10:10). The plot that received fish pond effluent alone at $40,000 \mathrm{~L} / \mathrm{ha}$ recorded $33.6 \mathrm{~cm}$ while the Control was $26.87 \mathrm{~cm}$. The results presented on Table 5 showed that, Fish Pond Effluent when applied singly as well as its combination with fertilizer (NPK 20:10:10) increased the number of branches at all the developmental stages when compared with the Control and were therefore significantly $(\mathrm{P}=0.05)$ different.

The highest Number of branches (2.80) was recorded at the plot where fish pond effluent was applied at 20,000 litres / hectare + 200kg/ha fertilizer (NPK 20:10:10) at 7 weeks after planting (WAP).

The results on Table 6 indicated that, Fish Pond Effluent increased the Leaf Area of Cucumber when compared with the Control at all the developmental stages and there was significant difference among the treatments. The highest leaf area $\left(48.60 \mathrm{~cm}^{2}\right)$ was recorded at the plot that received Fish Pond Effluent at the rate of $20,000 \mathrm{~L} / \mathrm{ha}$ combined with 200kg/ha of NPK Fertilizer 20:10:10,

The results of the study showed that, soil chemical properties and growth parameters of cucumber were enhanced as a result of application of fish pond effluent singly as well as its combination with inorganic fertilizer (NPK 20: 10: 10).

This enhancement could be attributed to the high content of nutrients released into Fish Pond Effluent. Formulated feeds and large amounts of green/ animal manures introduced / applied to fish ponds, led to accumulation of organic matter at the bottom of the ponds and other vital nutrients like Nitrogen and 
phosphorus which have significantly improved the soil fertility level of the studied area and growth of cucumber.

Results obtained on analysis of soil chemical properties of the studied area, indicated that application of Fish Pond Effluent at the rate of 40,000 litres/hectare increased the Total Nitrogen, Available Phosphorus, Organic Carbon and Organic Matter when compared with the Control. Combination of 20,000litres/ha of fish pond effluent with $200 \mathrm{~kg} / \mathrm{ha}$ of NPK $(20: 10: 10)$ fertilizer further increased the values of Total Nitrogen; Available Phosphorus, Organic Carbon and Organic Matter as a result of the nutrients supplied from both the pond effluent and added NPK fertilizer. These results were supported by the results obtained by Ojobor and Tobih (2015), Dominic and Otobong (2016). The increased values noted in the growth components of Cucumber (namely: Number of leaves, vine length, Number of branches and leaf Area in the studied area with the application of fish pond Effluent singly and its combination with NPK Fertilizer (20:10:10) could be attributed also to the increased rate of mineral nutrition and photosynthetic processes occasioned by high content of Nutrients (Nitrogen, Phosphorus, organic carbon and organic matter) in the fish pond effluent and the nutrients added from NPK fertilizer.

Table.1 Physical and chemical properties of soil of the experimental site before treatment

\begin{tabular}{|c|c|}
\hline Soil Properties & Values \\
\hline \multicolumn{2}{|l|}{ Physical characteristics } \\
\hline \multicolumn{2}{|l|}{ Particle size $(\mathrm{g} / \mathrm{kg})$} \\
\hline Fine sand & 43 \\
\hline Course sand & 40 \\
\hline Silt & 5 \\
\hline Clay & 12 \\
\hline Textural class & LS \\
\hline \multicolumn{2}{|l|}{ Chemical characteristics } \\
\hline pH $\left(\mathbf{H}_{2} \mathbf{0}\right)$ & 5.8 \\
\hline pH (Kcl) & 4.7 \\
\hline Available phosphorus (mg/kg) & 7.60 \\
\hline Total nitrogen $(\mathrm{g} / \mathrm{kg})$ & 0.70 \\
\hline Organic carbon $(\mathrm{g} / \mathrm{kg})$ & 5.55 \\
\hline Organic Matter (g/kg) & 9.57 \\
\hline \multicolumn{2}{|l|}{ Exchangeable bases $(\mathrm{cmol} / \mathrm{kg})$} \\
\hline $\mathrm{Ca}^{2+}$ & 8.40 \\
\hline $\mathrm{Mg}^{2+}$ & 2.00 \\
\hline $\mathbf{K}^{+}$ & 0.08 \\
\hline $\mathrm{Na}^{+}$ & 0.03 \\
\hline $\mathrm{CEC}(\mathrm{cmol} / \mathrm{kg})$ & 14.00 \\
\hline Base Saturation (\%) & 75.07 \\
\hline \multicolumn{2}{|l|}{ Exchangeable Acidity $(\mathrm{cmol} / \mathrm{kg})$} \\
\hline $\mathrm{Al}^{3+}$ & - \\
\hline $\mathbf{H}^{+}$ & 1.40 \\
\hline
\end{tabular}


Table.2 Effect of fish pond effluent on soil chemical properties of Igbariam

\begin{tabular}{|lcccccc|}
\hline Treatment & \multicolumn{2}{c}{$\mathbf{p H}$} & $\begin{array}{c}\text { P } \\
(\mathrm{mg} / \mathrm{kg})\end{array}$ & $\begin{array}{c}\mathrm{N} \\
(\mathrm{g} / \mathrm{kg})\end{array}$ & $\begin{array}{c}\mathrm{OC} \\
(\mathrm{g} / \mathrm{kg})\end{array}$ & $\begin{array}{c}\text { OM } \\
(\mathrm{g} / \mathrm{kg})\end{array}$ \\
\hline Control (No treatment) & 5.8 & 4.43 & 4.79 & 0.56 & 3.4 & 5.9 \\
\hline F P E (40,000 L/ha) & 5.9 & 5.57 & 5.73 & 0.7 & 4.4 & 7.6 \\
\hline $\begin{array}{l}\text { FPE +F } \\
(20,000 \mathrm{~L} / \mathrm{ha}+200 \mathrm{~kg} / \mathrm{ha})\end{array}$ & 5.97 & 4.83 & 6.66 & 0.8 & 5.8 & 10.1 \\
\hline LSD 0.05 & NS & NS & 0.09 & 0.04 & 0.11 & 0.72 \\
\hline
\end{tabular}

Table.3 Effect of fish pond effluent on number of leaves of cucumber

\begin{tabular}{|l|l|l|l|}
\hline Treatment & $\mathbf{5}$ & $\begin{array}{l}\text { WAP } \\
\mathbf{6}\end{array}$ & $\mathbf{7}$ \\
\hline Control (No treatment) & 11.4 & 14.2 & $\mathbf{2 0 . 9}$ \\
\hline FPE $(\mathbf{4 0 , 0 0 0 L / h a )}$ & 15.5 & 19.0 & $\mathbf{3 3 . 7}$ \\
\hline FPE +F(20,0000L/ha+200kg/ha) & 23.8 & 28.9 & \\
\hline & & & $\mathbf{3 7 . 9}$ \\
\hline LSD 0.05 & $\mathbf{3 . 9 9}$ & $\mathbf{6 . 3 5}$ & $\mathbf{1 0 . 2 2}$ \\
\hline
\end{tabular}

WAP - Weeks After Planting; FPE - Fish Pond Effluent F - Fertilizer (NPK 20:10:10); LSD - Least Significant Difference.

Table.4 Effect of Fish Pond Effluent on Vine Length of Cucumber $(\mathrm{cm})$

\begin{tabular}{|l|l|l|l|}
\hline Treatment & $\mathbf{5}$ & $\begin{array}{l}\text { WAP } \\
\mathbf{6}\end{array}$ & $\mathbf{7}$ \\
\hline Control (No treatment) & 11.8 & 18.93 & $\mathbf{2 6 . 8 7}$ \\
\hline FPE (40,000L/ha) & 15.3 & 21.93 & $\mathbf{3 3 . 6}$ \\
\hline FPE +F(20,0000L/ha+200kg/ha) & 26.7 & 31.27 & $\mathbf{3 9 . 4 7}$ \\
\hline & & & \\
\hline LSD 0.05 & $\mathbf{2 . 8 0}$ & $\mathbf{2 . 2 5}$ & $\mathbf{7 . 2 5}$ \\
\hline $\begin{array}{l}\text { WAP - Weeks after planting; FPE - Fish Pond Effluent, F - Fertilizer (NPK 20:10:10); LSD - Least Significant } \\
\text { Difference; NS - Not Significant }\end{array}$ & & \\
\hline
\end{tabular}


Table.5 Effect of fish pond effluent on number of branches of cucumber

\begin{tabular}{|l|l|l|l|}
\hline Treatment & $\mathbf{5}$ & $\begin{array}{l}\text { WAP } \\
\mathbf{6}\end{array}$ & $\mathbf{7}$ \\
\hline Control (No treatment) & 1.42 & 1.47 & $\mathbf{2 . 0 0}$ \\
\hline FPE (40,000L/ha) & 1.77 & 2.07 & $\mathbf{2 . 4 0}$ \\
\hline FPE +F(20,0000L/ha+200kg/ha) & 2.00 & 2.27 & $\mathbf{2 . 8 0}$ \\
\hline & & & \\
\hline LSD 0.05 & $\mathbf{0 . 3 5}$ & $\mathbf{0 . 6 1}$ & $\mathbf{0 . 2 8}$ \\
\hline
\end{tabular}

WAP - Weeks After Planting; FPE - Fish Pond Effluent; F- Fertilizer (NPK 20:10:10); LSD - Least Significant Difference; NS - Not Significant.

Table.6 Effect of fish pond effluent on leaf area of cucumber $\left(\mathrm{cm}^{2}\right)$

\begin{tabular}{|l|l|l|l|}
\hline Treatment & $\mathbf{5}$ & $\begin{array}{l}\text { WAP } \\
\mathbf{6}\end{array}$ & $\mathbf{7}$ \\
\hline Control (No treatment) & 23.28 & 25.89 & $\mathbf{2 8 . 4 9}$ \\
\hline FPE (40,000L/ha) & & & \\
\hline FPE +F(20,0000L/ha+200kg/ha) & 42.81 & 44.09 & $\mathbf{4 8 , 4 0}$ \\
\hline & & & \\
\hline LSD 0.05 & $\mathbf{8 . 5 7}$ & $\mathbf{8 . 3 5}$ & $\mathbf{4 8 . 1 4}$ \\
\hline
\end{tabular}

WAP - Weeks After Planting; FPE - Fish Pond Effluent; F - Fertilizer (NPK 20: 10:10); LSD - Least Significant Difference; NS - Not Significant.

The results obtained in these growth parameters agreed with the works of Egharevba and Ogbe (2002); Ojobor and Tobih (2016).

In conclusion, the results of the study indicated that fish pond effluent increased both the soil chemical properties and growth parameters of Cucumber and as such, it is recommended to be utilized as Organic Fertilizer to improve Soil Fertility level and growth of Cucumber in the studied area.. Combination of fish pond effluent at the rate of 20,000 litres/ha with $200 \mathrm{~kg} / \mathrm{ha}$ of $\mathrm{NPK}$ $(20 ; 10: 10)$ fertilizer gave the highest results in all the parameters accessed except the leaf Area where the results obtained were at par with that of fish pond effluent singly applied.

\section{References}

Adeniyan, O.N. Ojo, A.O., Akinbode, O.A. and Adediran J.A. (2011). Comparative study of different organic manures and $\mathrm{NPk}$ fertilizer for improvement of soil chemical properties and dry matter yield of maize in two different soils. Journal of Soil Science and Environmental Msanagement. 2(1) 9-13.

Agba, O.A. and Enya V.E. (2005). Response of Cucumber to Nitrogen in Cross River state of Nigeria. Global Journal of Agricultural Science 4:165 - 167.

Alter T.R. (2000) Cucumber production. Agricultural alternative publication of the small scale and part time farming 
project. The Pennyslavia state university, pp 6:

Avnimelech, Y; Moses, N., Diab G. and Kochba, M. (1995). Rates of organic carbon and nitrogen degradation in intensive fish pond, Aquaculture 93: $1156-1163$.

Avnimelech, Y. (1998) Minimal discharge from intensive fish ponds. World Aquaculture 9:32 - 37 .

Black, C.A. Evans, D.D., White, J.L. Ensmingen, L.E. and Clark 'F. E. (eds) (1965). Methods of soil analysis part 2 agronomy Madison, soil science society of America.

Bray, R. H and Kurtz, L.T. (1945). Determination of total organic and available forms of phosphorus in soils. Soil science 59: 39 - 48 .

Dominic J. Udoh and Otobong B. Iren (2016) Evaluation of Fish Pond effluent as an organic fertilizer in comparison with poultry and Pig Manure, in the cultivation of Pineapple (Ananas comosus) 10SR Journal of Agriculture and Veterinary Science (10SR - JAVS) Vol 9 Issue 9 Ver. 11 pp $05-10$.

Dr. A. Shrivastava Dr. S. Roy, Cucurbitaceal (2013); Aethnomedicinally important vegetable family. Journal of medicinal plant studies, 1 (4): $16-20$.

Egbarev BA, R.K.A. and Ogbe, F.M. (2002) The effects of different levels of organic and mineral fertilizer on the yield performance of two Amaranthus cultivars. The Plant Scientists 3: $62-$ 72.

Eifediyi E.K; Remison S.U. (2009), Effect of inorganic fertilizer on growth and yield of two varieties of Cucumber. Dept of Crop Science, Ambrose Alli University Ekpoma, Nigeria

FAO (Food and Agriculture Organization of the United Nation) (2014). The State of world Fisheries and Acquaculture, Opportunities and Challenges, FAO,
Rome.

Granstedt, A. (1992). The Potential for Swedish farms to eliminate the use of artificial fertilizers. American Journal of Alternative Agriculture, 6 (3), 122 131.

Grubben vegetable, G.J.H. (1997). Tropical and their genetic resources Royal Tropical Institute Amsterdam Netherlands 453 pp.

Iren, O. B., Akpan J. F. Ediene, V.F. and Asanga E.E. (2015). Influence of Cassava peels and poultry manure based compost on soil properties, growth and yield of water leaf. (Talinum triangular Jacq.) in an ultisol of South - Eastern Nigeria. Journal of soil science and environmental management 6 (7), 187 194

Kashif W. Kamran O.M. Jilani M.S. (2008) Effect of different mtroben levels on growth and yield of Cucumber J. Agric. Res 46 (3)259, 266

Lawal, A.B. (2000) Response of Cucumber to inter cropping with maize and varying rates of farm yard manure and inorganic fertilizer.

Nsoanya,L.N. and Nweke I.A. (2015) Effect of integrated use of Spent Grain and NPK (20:10:10) fertilizer on Soil Chemical Properties and. Maize (Zea mays) Growth. International Journal of Research in Agriculture and Forestry Vol 2, issue 3 pp $14-19$.

Nweke I.A. and Nsoanya, L.N. (2013) Effect of Poultry manure and inorganic fertilizer on the performance of Marze (Zea mays L) and selected physical properties of soils of Igbariam South Eastern Nigeria. Int. J. Agric Rural Dev. 16 (1): 1348 - 1353.

Ojobor S.A. and Tobih F. O. (2015). Effects of fish Pond effluent and inorganic Fertilizer on Amaranthus yield and soil chemical properties in Asaba, Delts State Nigeria. Journal of Agriculture 
and Environmental Sciences Vol 4. No 1, pp $237-244$.

Paul, K., Kandhere, A., Bhise, D. (2012) Pharmacological evaluation of ameliorative effect of aqueous extracts of Cucumis sativas L. fruit formation on wound healing in Wister rat. Chronicle of Young Scientists.

Peat, M. (2001) Sustainable Practices for vegetable production in the south, North Carolina State University.

Steel, G.D. and Torrie, J. H. (1980). Principles and procedures of statistics. A biometrical approach, $2^{\text {nd }}$ edition McGraw Hill book CO. Inc. New York pp 633.

Tindall, H.D. (1986) Vegetable in the Tropics Mac Edu. Ltd Hampshire UK.

Udoh, D. J., Iren, O. B. and Jonathan, J.E. (2016) Comparison of fish pond waste with manures under garden egg (Solanum spp) in Nigeria. Environment and Natural resources research 6 (3) 58 -64 .

Walkley, A. and Black, I.A. (1934). An examination of the Degtjareff method for determining soil organic matter and the proposed modification of the chromic acid titration method. Soil science $37: 29-38$.

\section{How to cite this article:}

Nsoanya Leonard Ndubuisi. 2019. Response of Fish Pond Effluent on Soil Chemical Properties and Growth of Cucumber (Cucumis sativus) in Igbariam South Eastern, Nigeria. Int.J.Curr.Microbiol.App.Sci. 8(02): 2799-2807. doi: https://doi.org/10.20546/ijcmas.2019.802.329 